\title{
NCAM2 Gene
}

National Cancer Institute

\section{Source}

National Cancer Institute. NCAM2 Gene. NCI Thesaurus. Code C90034.

This gene may be involved in fasciculation and olfaction. 